\title{
Lifestyle Changes that Impact Personal Quality of Life in the COVID-19 Pandemic in South Korea
}

\author{
Young Rong Bang ${ }^{1}$, Seon-Cheol Park ${ }^{2}$, Ok-Jin Jang ${ }^{3}$, Joon Hee Kim \\ Eun Ok Kim ${ }^{4}$, Seong Hwan Kim ${ }^{1,5}$, and Jae Hong Park ${ }^{1,4,5} \bowtie$ \\ ${ }^{1}$ Department of Psychiatry, Dong-A University Hospital, Busan, Republic of Korea \\ 2Department of Psychiatry, Hanyang University Guri Hospital, Guri, Republic of Korea \\ ${ }^{3}$ Department of Psychiatry, Bugok National Hospital, Changyeong, Republic of Korea \\ ${ }^{4}$ Busan Regional Mental Health Welfare Center, Busan, Republic of Korea \\ ${ }^{5}$ Department of Psychiatry, College of Medicine, Dong-A University, Busan, Republic of Korea
}

\begin{abstract}
Objective We investigated which factors in psychological changes positively or negatively affect the quality of life to suggest desirable directions in the period of the COVID-19 pandemic.

Methods Online survey was conducted with 1,011 adults more than 19 years old in Busan, South Korea. Quality of life was measured using the World Health Organization Quality of Life-BREF. Questions regarding the psychological changes were about COVID-19-related concerns, distress in complying with quarantine guidelines, and interest in seeking something to do alone.

Results Quality of life was perceived to be below average (mean $\pm \mathrm{SD}, 2.86 \pm 0.53$ ). The more economic worries there were, the lower the quality of life in psychological, social relationships and environmental domains. The more distress one experienced when maintaining their personal hygiene, the higher the quality of life related to their physical health. Likewise, the more difficult it was to maintain social distances, the higher the quality of life associated with psychological and social relationships. The more interested someone was in how to spend time alone, the higher the quality of life in all domains significantly.
\end{abstract}

Conclusion We can minimize the negative impacts of COVID-19 by maintaining economic stability, maintaining prosocial behaviors related to personal hygiene and making good use of personal time.

Psychiatry Investig 2021;18(7):701-707

Key Words COVID-19, Coronavirus, Pandemic, Quality of life, Social distancing.

\section{INTRODUCTION}

On March 11, 2020, the WHO declared the new coronavirus to be a pandemic, and the risk of infection is still ongoing. In South Korea, starting with the first COVID-19 confirmed on January 22, 2020, coronavirus infections soared at the end of February 2020 due to group gatherings. In order to prevent the spread of infection, the Korean government postponed school openings for students starting in March and launched a high-intensity "social distancing" campaign until May. Social distancing was a recommended part of the public quar-

Received: February 4, 2021 Revised: April 26, 2021

Accepted: May 9, 2021

$\triangle$ Correspondence: Jae Hong Park MD, PhD

Department of Psychiatry, Dong-A University Hospital, Dong-A University College of Medicine, 26 Daesingongwon-ro, Seo-gu, Busan 49201, Republic of Korea

Tel: +82-51-240-5467, Fax: +82-51-253-3542, E-mail: drpark@dau.ac.kr

(c) This is an Open Access article distributed under the terms of the Creative Commons Attribution Non-Commercial License (https://creativecommons.org/licenses/bync/4.0) which permits unrestricted non-commercial use, distribution, and reproduction in any medium, provided the original work is properly cited. antine implemented for the purpose of minimizing contact between people, and it included complying with personal hygiene rules, delaying or canceling events or meetings, refraining from going out unnecessarily, keeping more than 2 meters between people, and not shaking hands.

Infectious diseases such as large-scale outbreaks (e.g., Ebola virus disease epidemic from 2014 to 2016) have wide influences that impact the majority of the general public because of no defined places or over a limited time, which makes the boundaries of their impacts relatively clear. ${ }^{1,2} \mathrm{~A}$ series of lifestyle changes include frequent exposure to information about the spread of COVID-19, complying with quarantine guidelines, limiting daily life and social activities related to communication, and various economic problems such as unemployment or leaves of absence are sufficient to increase an individual's psychological distress, such as their anxiety, fear, worry and exhaustion as well as quality of life. ${ }^{3}$ Since a lot of papers related COVID-19 are pouring out until now, investigations for subjects who were medical staff or patients who 
already had psychological problems were relatively well known. ${ }^{4}$ Instead, we tried to estimate the quality of life regarding living in the COVID-19 pandemic with a general community sample. The purpose of this study is to investigate the degree of the psychological responses due to lifestyle changes and quality of life after COVID-19 pandemic, and to inform certain changing behaviors or psychological responses that contribute to improving the quality of life. We also investigated which factors in the psychological responses positively or negatively affect the quality of life to suggest desirable directions in the period of the COVID-19 pandemic.

\section{METHODS}

\section{Study design and participants}

A cross-sectional online survey was conducted in the metropolitan city of Busan, South Korea. We conducted this study from 28 April until 12 May, 2020. This was a period of the coronavirus pandemic where the infection rate rose to its peak and stabilized to some degree, and the high-intensity social distancing policy was continued for several months. The participants in this study consisted of 1,011 adults more than 19 years old. The sample was selected using proportional stratified sampling between panels from the Gallup Korea Cooperation research agency. The sample consisted of group of people from Busan that was representative in terms of gender, age, and residential area. Informed consent was obtained from all of the participants included in the study. The study protocol was approved by the Institutional Review Board of Dong-A University Hospital (IRB No. DAUHIRB-20-104).

\section{Quality of life as an outcome measure}

Quality of life was measured using the World Health Organization Quality of Life-BREF (WHOQOL-BREF). The WHOQOL-BREF is a self-report questionnaire comprising 26 items that assess 4 domains of the quality of life: physical health, psychological health, social relationships, and environment. The time frame was set to 1 month. We calculated the scores for each domain according to the scoring guidelines in the WHOQOLBREF manual. ${ }^{5}$ In our study, the internal consistency coefficient (Cronbach's alpha) for the WHOQOL-BREF was 0.91.

\section{Psychological responses related with lifestyle changes after COVID-19}

Three psychiatrists, one infectious medicine specialist and four mental health professionals (one clinical psychologist and three social workers) developed the questionnaire for this study. Our questionnaire was developed based on the literature review and expert opinions about infectious disease outbreaks. The questionnaire comprised 6 questions about re- sponses related with psychological responses due to lifestyle changes after COVID-19, including the following: COVID-19 related concerns, difficulties complying with the quarantine guidelines, and interest in alternative coping behavior (Korean version in Supplementary Table 1 in the online-only Data Supplement). Three questions were asked about COVID19-related concerns: "I am worried that I will get Coronavirus disease", "I am concerned about the financial difficulties (unemployment, unpaid leave, closing out, etc.) caused by the Coronavirus disease", "I am concerned that social distancing will make interpersonal relationships difficult." Before asking questions about complying with quarantine guidelines, we presented the Korea Centers for Disease Control and Prevention (KCDC) quarantine guidelines ${ }^{6}$ including recommendations for personal hygiene (wash your hands; cover your mouth with your sleeve when coughing; do not touch your eyes, nose, or mouth with unwashed hands; and wear a facemask) and social distancing (stay home, delay or cancel nonessential gatherings, and avoid visiting crowded places). Then, we asked two questions: "How difficult has it been to comply with the personal hygiene recommendations in the past month?" and "How difficult has it been to keep social distancing in the past month?" Additionally, we asked one question about interest in seeking something to do alone: "I seek ways that I could enjoy my time alone during the social distancing period." All the questions were scored on a 5-point Likert scale including not at all (1), a little (2), a moderate amount (3), very much (4) and an extreme amount (5). The internal consistency coefficient (Cronbach's alpha) for this 6-tiem questionnaire was 0.77 .

\section{Sociodemographic data as covariates}

We selected sociodemographic variables that have been known to be associated with quality of life in previous studies. $^{7.8}$ Sex (male and female), age (years), educational level (12 years and under and over 12 years), marital status (never married, married, divorced, and widowed), occupational status (employed or self-employed, unemployed, homemaker, and student), religion, number of family members ( 1 to 5 or more), and monthly household income (below 2 million Korean Won (KRW) to above 6 million KRW) were measured. These variables were included in our analysis as covariates.

\section{Statistical analysis}

The SPSS statistical computer package (version 22.0; IBM Corp., Armonk, NY, USA) was used for all statistical analyses. The descriptive statistics, such as the frequency, mean and standard deviations, were computed to describe the characteristics of the study population. The questionnaire's reliability was examined using Cronbach's alpha coefficient. Multiple linear regression analysis was performed to ascertain the pre- 
dictors of quality of life. Before the regression analyses, the autocorrelation (Durbin-Watson) and multicollinearity (variance inflation factor and tolerance) were checked. In our regression model, the dependent variable was the summed score of the 4 domains of WHOQOL-BREFF, and the independent variables were the scores of the COIVD 19-related concerns, the feeling difficulties in complying with quarantine guidelines, and interest in seeking something to do alone. The covariates considered in the analytic models were sex, age, educational level, occupational status, marital status, religion, number of family members, and monthly household income. The statistical significance was evaluated using a two-sided design with alpha set to 0.05 .

\section{RESULTS}

\section{Participant characteristics}

Of the 1,011 participants who completed the questionnaire, the proportion of sex was similar with 526 males (52\%) and 485 females (48\%) (Table 1). The mean age of the participants was $46.8 \pm 15.1$ (range 19-88), and 686 (68\%) of them had a higher level of education. In terms of employment status, 626 (62\%) had a job, 167 (16.5\%) were homemakers, 147 (14.5\%) had no job (i.e., unemployed or retired), and 71 (7\%) were students. Approximately $60 \%$ of participants were married and living with someone else at the time of the study. More than half of the participants $(57.7 \%)$ indicated no religious preference. The majority of the participants $(87.7 \%)$ were living with one or more family members. The percentage shares for the categories of the number of family members including the participants were reported in the following order: four (31.3\%), three $(26.3 \%)$, two (13.9\%), alone (12.3\%) and five or more $(6.2 \%)$. The economic status of the participants was evenly distributed from the bottom to the top.

\section{The degree of quality of life and psychological responses about lifestyle changes}

Individuals' overall perception of their quality of life score was $2.86 \pm 0.53$, reflecting an average quality state (Table 2 ). Among the four domains of the quality of life, psychological health was perceived the lowest $(10.7 \pm 2.49)$. The scores of physical health, environment and social relationships were $11.14 \pm 2.18,11.84 \pm 2.55$ and $12.23 \pm 3.03$, respectively, and they increased in sequence. Regarding COVID-19-related concerns, the mean scores of the questions about worry about getting infected and concern about financial difficulties were $3.22 \pm 1.21$ and $3.1 \pm 1.3$. The mean score of question about concern about interpersonal relationships was $2.48 \pm 1.23$. The mean scores of questions about feeling difficulties from complying with quarantine guidelines were as follows: $2.18 \pm 0.97$
Table 1. Sociodemographic characteristics of participants (All= 1,011)

\begin{tabular}{|c|c|}
\hline Variables & $\mathrm{N}(\%)$ \\
\hline Age (mean \pm SD) & $46.8 \pm 15.1$ (range $19-88)$ \\
\hline \multicolumn{2}{|l|}{ Sex } \\
\hline Male & $526(52.0)$ \\
\hline Female & $485(48.0)$ \\
\hline \multicolumn{2}{|l|}{ Education } \\
\hline 12 years and under & $325(32.1)$ \\
\hline Above 12 years & $686(67.9)$ \\
\hline \multicolumn{2}{|l|}{ Occupational status } \\
\hline Unemployed or retired & $147(14.5)$ \\
\hline Employed or self-employed & $626(62.0)$ \\
\hline Housemaker & $167(16.5)$ \\
\hline Student & $71(7.0)$ \\
\hline \multicolumn{2}{|l|}{ Marital status } \\
\hline Never married & $366(36.2)$ \\
\hline Married & $589(58.3)$ \\
\hline Divorced & $33(3.3)$ \\
\hline Widowed & $23(2.3)$ \\
\hline \multicolumn{2}{|l|}{ Religion } \\
\hline Yes & $428(42.3)$ \\
\hline No & $583(57.7)$ \\
\hline \multicolumn{2}{|c|}{ Number of family members (including participants) } \\
\hline Alone & $124(12.3)$ \\
\hline 2 members & $242(23.9)$ \\
\hline 3 members & $266(26.3)$ \\
\hline 4 members & $316(31.3)$ \\
\hline 5 members and above & $63(6.2)$ \\
\hline \multicolumn{2}{|l|}{ Monthly income (KRW) } \\
\hline Below 2 million & $205(20.3)$ \\
\hline$<3$ million & $181(17.9)$ \\
\hline$<4$ million & $169(16.7)$ \\
\hline$<5$ million & $175(17.3)$ \\
\hline$<6$ million & $105(10.4)$ \\
\hline Above 6 million & $176(17.4)$ \\
\hline
\end{tabular}

Variables are presented as $\mathrm{N}(\%)$ or mean \pm standard deviation (SD). One US dollars is equivalent to about 1,200 KRW

for personal hygiene and $2.63 \pm 1.13$ for social distancing. The interest in seeking something to do alone showed $2.96 \pm 1.15$ as the mean score.

\section{Predictors that impact quality of life}

When the relationship between each of the four domains regarding quality of life and the psychological responses related with lifestyle changes was investigated (Table 3), worry 
Table 2. The scores of questionnaires related to quality of life and psychological responses related with lifestyle changes after COVID-19

\begin{tabular}{|c|c|c|c|c|}
\hline & Min & Max & Mean & $\mathrm{SD}$ \\
\hline \multicolumn{5}{|l|}{ WHOQOL_BREF } \\
\hline Overall & 1 & 5 & 2.86 & 0.53 \\
\hline Physical health & 4 & 20 & 11.14 & 2.18 \\
\hline Psychological health & 4 & 20 & 10.70 & 2.49 \\
\hline Social relationships & 4 & 20 & 12.23 & 3.03 \\
\hline Environment & 4 & 20 & 11.84 & 2.55 \\
\hline \multicolumn{5}{|c|}{ Psychological responses related with lifestyle changes } \\
\hline Worry about getting infected & 1 & 5 & 3.22 & 1.21 \\
\hline Concern about financial difficulties & 1 & 5 & 3.10 & 1.30 \\
\hline Concern about interpersonal relationship & 1 & 5 & 2.48 & 1.23 \\
\hline Difficulty in complying personal hygiene & 1 & 5 & 2.48 & 0.97 \\
\hline Difficulty in keeping social distancing & 1 & 5 & 2.63 & 1.13 \\
\hline Seeking something to do alone & 1 & 5 & 2.96 & 1.15 \\
\hline
\end{tabular}

WHOQOL_BREF: World Health Organization Quality of Life-BREF, SD: standard deviation

about getting infected and concern about interpersonal relationships had no significant relationship with quality of life. Physical health was significantly positively associated with difficulty from keeping personal hygiene $(\mathrm{B}=0.18, \mathrm{SE}=0.09$, $\mathrm{p}=0.02)$ and seeking something to do alone $(\mathrm{B}=0.24, \mathrm{SE}=0.07$, $\mathrm{p}=0.001$ ). Psychological health was related with low worries about financial difficulties $(\mathrm{B}=-0.18, \mathrm{SE}=0.07, \mathrm{p}=0.011)$, high difficulty from complying social distancing $(\mathrm{B}=0.2, \mathrm{SE}=0.07$, $\mathrm{p}=0.005$ ) and a high degree of seeking something to do alone $(\mathrm{B}=0.45, \mathrm{SE}=0.08, \mathrm{p}<0.001)$. Social relationships were also associated with the three previous conditions (financial difficulties, $\mathrm{B}=-0.32, \mathrm{SE}=0.09, \mathrm{p}<0.001$; high difficulty from complying social distancing, $\mathrm{B}=0.2, \mathrm{SE}=0.09, \mathrm{p}=0.027$; high seeking something to do alone, $\mathrm{B}=0.23, \mathrm{SE}=0.1, \mathrm{p}=0.021)$. Environment was significantly associated with low worry about financial difficulties $(\mathrm{B}=-0.28, \mathrm{SE}=0.08, \mathrm{p}<0.001)$ and a high degree of seeking something to do alone $(\mathrm{B}=0.38, \mathrm{SE}=0.08, \mathrm{p}<0.001)$. More detailed information about a relationship between covariates and quality of life was presented in Supplementary Table 2 (in the online-only Data Supplement).

\section{DISCUSSION}

During the COVID-19 pandemic period, we investigated how people feel about their quality of life and various psychological changes that occurred in a metropolitan city in South Korea. Quality of life was perceived to be below average, and psychological health was evaluated as the lowest compared to other parts (physical, social, and environment). Overall distress from the psychological changes that were reported was also moderate. There was anxiety about infection, financial difficulties, and interpersonal relationships, distress regarding keeping personal hygiene and following social distancing guidelines, and increasing interest in how to spend time alone. When we examined the associations between quality of life and psychological changes, the more economic worries one experienced, the lower their quality of life in the psychologi$\mathrm{cal}$, social relationships and environmental domains excluding physical health. Interestingly, the more distress one experienced when maintaining their personal hygiene, the higher their quality of life related to physical health. Likewise, the more difficult it was to maintain social distancing, the higher the quality of life associated with psychological and social relationships. The more interested one was in in how to spend time alone, the better their assessed quality of life in all domains.

Quality of life was reported as an average of 2.9 points in May 2020, which is a reduced score compared to the 3.7 points reported when the same survey was conducted in 2019 in Busan. ${ }^{9}$ It may be considered that the decline in the quality of life is relatively milder than expected. This might be explained by South Koreans having previously experienced infectious diseases such as MERS in May 2015 and September 2018, which made them feel less anxious about COVID-19 in the period of this study. Compared to other countries, South Korea might show a calm and quick attitude when observing the government's quarantine guidelines, and there was hardly any social turmoil such as hoarding. Nevertheless, this result seems to be valid because a mild stressful state was reported in a previous study conducted in China. ${ }^{10}$ But psychological health plays an important role in increasing the adherence to public health measures such as vaccination and helping cope with the threat of infection and consequent losses. ${ }^{4}$ Adequate ad- 


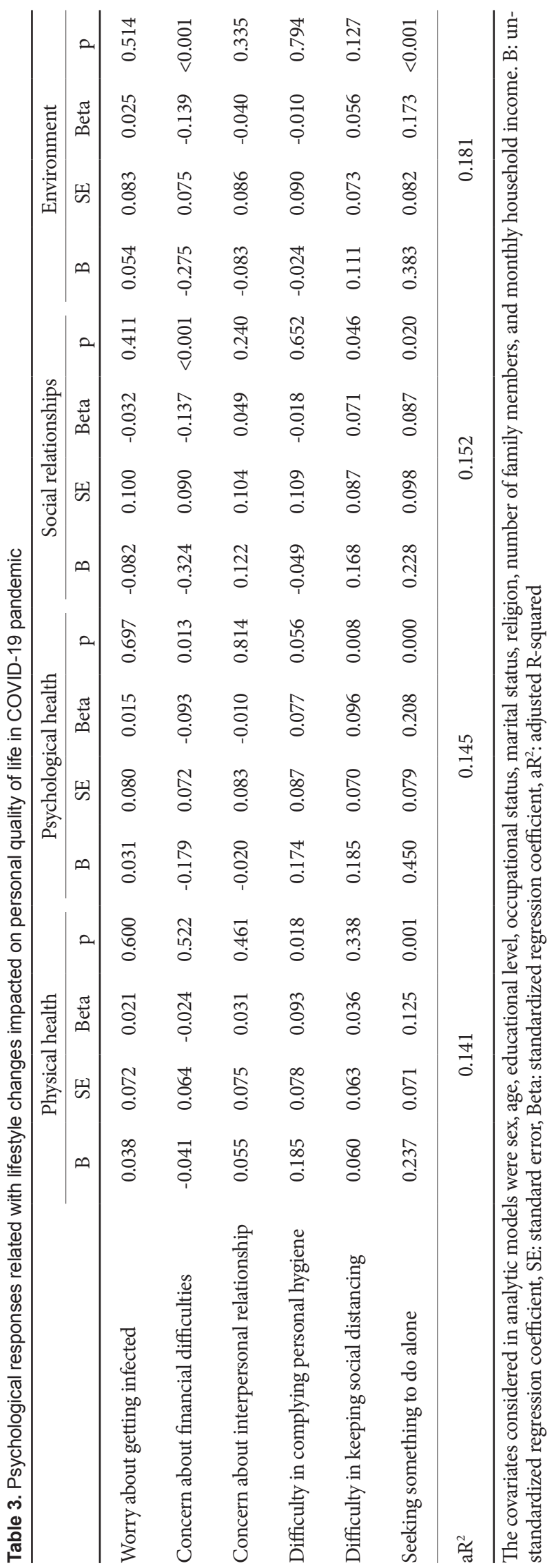

vancements in mental health care, including psychological crisis interventions and the provision of mental health assessment, support and treatment, due to the disaster of the COVID-19 pandemic is needed. ${ }^{11,12}$

It is easily predictable that worries about financial difficulties will lower the quality of life. The COVID-19 pandemic has curtailed the distribution and trade between many people and resulted in economic activities related to production and consumption coming to a standstill. This economic recession can cause common mental disorders and substance disorders, and economic recessions are known to be a major risk factor for suicide..$^{13}$ Considering the results of this study, it might be suggested that if governments respond quickly to economic problems, it will help to preserve or improve the quality of life for individuals.

In this study, the more difficult it is to observe personal hygiene practices including hand washing to prevent the spread of COVID-19, the higher the quality of physical life is evaluated. This result seems to be contrary to the results of previous studies, which complains of stress due to pandemic and mental health problems such as anxiety and depression, resulting in poor quality of life. ${ }^{14-16}$ This different result was made by that because we did not ask about the psychological difficulties caused by COVID-19 (e.g., social isolation) but rather that caused by following the quarantine guidelines for 'preventing' transmission of COVID-19. In other words, it is a redirectional or novel behavioral strategy that the goal of action is overcoming COVID-19. As with Ebola virus disease, ${ }^{1}$ COVID-19 outbreak made two behaviors, which were high-risk behaviors such as ignoring recommendations for social distancing and continuing to travel despite restrictions, and fearrelated behaviors such as extreme avoidance of social contact. $^{17}$ The fear-related behavior will likely result in increased risk of mental health problems, in contrast, psychoeducation and re-direction of fear-related behavioral responses during the outbreak can reduce risks of mental health and promote resilience. ${ }^{18}$ Thus, keeping quarantine guidelines might be stressful but could be an appropriate coping behavior to overcome in pandemic period neither the risky behavior nor the fearrelated behavior. This behavioral strategy might contribute to make positive mental health or improving quality of life. There are a few other hypotheses to consider. It might be suggested that a person who feels considerable distress while trying to maintain personal hygiene may feel some sense of satisfaction in that they have at the same time preserved their personal physical safety. Likewise, the more difficult they feel it is to practice social distancing while going out or engaging in meetings, the higher their satisfaction with life since these efforts have secured a sense of safety in their psychological health and social relationships. Or, those who worry about hygiene 
might be more diligent in health overall and therefore, healthier in general and score more highly on measures. The results of this study may be provide good evidence to support the compliance with the quarantine guidelines in the period of the COVID-19 pandemic since prosocial behaviors of adhering to the rules of personal hygiene and social distancing contribute to improving quality of life.

While the amount or frequency of social activities has decreased, the time one spends alone has increased in the period of the COVID-19 pandemic. Loneliness is reported as a risk factor for a variety of psychological conditions. ${ }^{19}$ Moreover, isolation will probably increase fear, anxiety, depression and loneliness and create significant psychological distress if isolation is maintained for a long period. ${ }^{16}$ Therefore, if we go through the period of the COVID-19 pandemic while actively looking for adaptive activities we can do by ourselves, we may experience less negative emotional reactions derived from isolation and less deteriorated feelings of quality of life. As explained above, it may be a re-directional behavioral strategy for 'handling' of social isolation. ${ }^{18}$ Infectious diseases such as pandemic did not always make negative psychological aspect. Some positive mental health have been reported after Sever Acute Respiratory Syndrome epidemic in Hong Kong. About 2/3 of the respondents paid more attention to their mental health and about $40 \%$ took more time to rest, for relaxation or doing exercise. These coping behavioral changes were considered to be important cushion of the negative impacts, including perception of stress and post-traumatic stress. ${ }^{20}$

There are several limitations in interpreting the results of this study. First, when measuring the quality of life due to the coronavirus epidemic, the timing and location of the investigation have decisive influences. This study was conducted on a community sample in the city of Busan and relatively early when the coronavirus epidemic spread nationwide. Thus, the results may differ from studies in other regions in South Korea or when coronavirus transmission was prolonged. Second, the psychological changes that affect quality of life have low explanatory power according to the statistical analyses. This is resulted from conduction of analysis using each of the 6 items separately, not as a whole. Third, our 6 items did not have an acquisition process of validity and could not capture important predictors of quality of life. Quality of life can be affected by various factors that we have not been able to measure, including an individual's characteristics (personality, resilience and alexithymia) and environmental aspects (inadequate supplies or information and social support). ${ }^{3}$ Future research will have to examine adequate variables that are more closely associated with quality of life in COVID-19. Fourth, we found that those who were able to spend time alone were less negatively affected on quality of life. It needs to be cautious to draw an interpretation because quality of life might be related with age or number of families living together. But, we adjusted age and the number of family members as covariates in the analyses and additionally confirmed that they did not significant impact on quality of life in this study.

COVID-19 has brought many life style and psychological changes to people around the world. Despite the occurrence of various negative impacts, we can minimize the impact by maintaining economic stability, keeping prosocial behaviors related to personal hygiene and making good use of personal time. Additionally, it may be possible to alleviate the mental tension prevailing in society by increasing social and family support and awareness of the importance of mental health. ${ }^{20}$ Because the prolonged COVID-19 pandemic is predicted, various efforts and attempts to find ways to protect mental health will be needed in the future.

\section{Supplementary Materials}

The online-only Data Supplement is available with this article at https://doi.org/10.30773/pi.2021.0043.

\section{Acknowledgments}

This work was supported by the Mental Health Research Project funded by the Government of Busan Metropolitan City.

\section{Conflicts of Interest}

The authors have no potential conflicts of interest to disclose.

\section{Author Contributions}

Conceptualization: Seon-Cheol Park, Ok-Jin Jang, Joon Hee Kim, Jae Hong Park. Data curation: Joon Hee Kim, Eun Ok Kim. Formal analysis: Joon Hee Kim, Eun Ok Kim. Funding acquisition: Jae Hong Park. Investigation: Joon Hee Kim, Eun Ok Kim, Seong Hwan Kim. Methodology: Joon Hee Kim, Jae Hong Park, Yong Rong Bang. Project administration: Joon Hee Kim, Eun Ok Kim. Supervision: Jae Hong Park. Validation: Seong Hwan Kim. Writing_original draft: Young Rong Bang. Writing_-review\&editing: Jae Hong Park, Seong Hwan Kim, Seon-Cheol Park, Ok-Jin Jang.

\section{ORCID iDs}

Young Rong Bang ～https://orcid.org/0000-0002-2803-6916

Seon-Cheol Park https://orcid.org/0000-0003-3691-4624

Ok-Jin Jang https://orcid.org/0000-0002-6272-7825

Joon Hee Kim https://orcid.org/0000-0002-4840-6320

Eun Ok Kim https://orcid.org/0000-0002-7874-972X

Seong Hwan Kim https://orcid.org/0000-0001-5707-5917

Jae Hong Park https://orcid.org/0000-0001-9710-4735

\section{REFERENCES}

1. Shultz JM, Baingana F, Neria Y. The 2014 Ebola outbreak and mental health: current status and recommended response. JAMA 2015;313: 567-568.

2. Cénat JM, Felix N, Blais-Rochette C, Rousseau C, Bukaka J, Derivois D, et al. Prevalence of mental health problems in populations affected by the Ebola virus disease: a systematic review and meta-analysis. Psychiatry Res 2020;289:113033.

3. Serafini G, Parmigiani B, Amerio A, Aguglia A, Sher L, Amore M. The psychological impact of COVID-19 on the mental health in the general population. QJM 2020;113:531-537. 
4. Kontoangelos K, Economou M, Papageorgiou C. Mental health effects of COVID-19 pandemia: a review of clinical and psychological traits. Psychiatry Investig 2020;17:491-505.

5. World Health Organization. Division of Mental Health. WHOQOLBREF: Introduction, Administration, Scoring and Generic Version of the Assessment: Field Trial Version. Geneva: World Health Organization; 1996.

6. KCDC leads the world free of diseases. Available at: http://nqs.cdc. go.kr/nqs/main.do. Accessed Feb 5, 2021.

7. Sagayadevan V, Jeyagurunathan A, Lau YW, Shafie S, Chang S, Ong HL, et al. Cognitive insight and quality of life among psychiatric outpatients. BMC Psychiatry 2019;19:201.

8. Kim YJ, Kang SW. The quality of life, psychological health, and occupational calling of Korean workers: differences by the new classes of occupation emerging amid the COVID-19 pandemic. Int J Environ Res Public Health 2020;17:5689.

9. Busan Regional Mental Health Welfare Center. A Study on the Psychological Health of Busan City Status Survey Report 2019. Busan: Busan Regional Mental Health Welfare Center Press; 2019.

10. Zhang Y, Ma ZF. Impact of the COVID-19 pandemic on mental health and quality of life among local residents in Liaoning province, China: a cross-sectional study. Int J Environ Res Public Health 2020;17:2381.

11. Xiang YT, Yang Y, Li W, Zhang L, Zhang Q, Cheung T, et al. Timely mental health care for the 2019 novel coronavirus outbreak is urgently needed. Lancet Psychiatry 2020;7: 228-229.

12. Duan L, Zhu G. Psychological interventions for people affected by the COVID-19 epidemic. Lancet Psychiatry 2020;7:300-302.

13. Frasquilho D, Matos MG, Salonna F, Guerreiro D, Storti CC, Gaspar T, et al. Mental health outcomes in times of economic recession: a systematic literature review. BMC Public Health 2016;16:115.

14. Cosic K, Popovic S, Sarlija M, Kesedzic I. Impact of human disasters and COVID-19 pandemic on mental health: potential of digital psychiatry. Psychiatr Danub 2020;32: 25-31.

15. Cénat JM, Mukunzi JN, Noorishad PG, Rousseau C, Derivois D, Bukaka J. A systematic review of mental health programs among populations affected by the Ebola virus disease. J Psychosom Res 2020;131:109966.

16. Carvalho Aguiar Melo M, de Sousa Soares D. Impact of social distancing on mental health during the COVID-19 pandemic: an urgent discussion. Int J Soc Psychiatry 2020;66:625-626.

17. Shultz JM, Cooper JL, Baingana F, Oquendo MA, Espinel Z, Althouse BM, et al. The role of fear-related behaviors in the 2013-2016 West Africa Ebola virus disease outbreak. Current Psychiatry Reports 2016;18: 104.

18. Cénat JM, Mukunzi JN, Noorishad PG, Rousseau C, Derivois D, Bukaka J. A systematic review of mental health programs among populations affected by the Ebola virus disease. J Psychosom Res 2020;131: 109966.

19. India State-Level Disease Burden Initiative Mental Disorders Collaborators. The burden of mental disorders across the states of India: the Global Burden of Disease Study 1990-2017. Lancet Psychiatry 2020;7: 148-161.

20. Lau JT, Yang X, Tsui HY, Pang E, Wing YK. Positive mental health-related impacts of the SARS epidemic on the general public in Hong Kong and their associations with other negative impacts. J Infect 2006; 53:114-124. 
Supplementary Table 1. The Korean version questionnaire comprised 6 questions about psychological responses related with lifestyle changes in COVID-19 다음은 지난 한달 동안 코로나 19 와 관련된 당신의 일상 생활과 관련하여 어떻게 느꼈는지 알아보는 문항입니다. 각 문항을 읽고 해당하는 부분에 체크해주세요.

1. 나는 지난 한달 동안 코로나 19 에 감염될까 불안했다.

2. 나는 코로나19로 인한 경제적 어려움(실직, 무급휴가, 폐업 등)이 걱정된다.

3. 나는 사회적 거리두기로 인해 대인관계가 소원해질까 걱정된다.

4. 지난 한달 동안 코로나 19 전파방지를 위한 개인 위생 예방수칙을 지키는 것이 얼마나 힘들었나요?

5. 지난 한달 동안 코로나 19 전파방지를 위한 사회적 거리두기를 지키는 것이 얼마나 힘들었나요?

6. 나는 코로나 19로 인해 혼자 시간을 보내는 방법에 대해 관심이 생겼다.
(1) (2) (3)

전혀 그렇지 않다

(1)

전혀 그렇지 않다

(1)

전혀 그렇지 않다

(1)

전혀 힘들지 않다

(1)

전혀 힘들지 않다

(1)

전혀 그렇지 않다
약간 그렇다 그렇다

(2) (3)

약간 그렇다 그렇다

(2) (3)

약간 그렇다 그렇다

(2) (3)

약간 힘들다 힘들다

(2)

약간 힘들다

(2)

약간 그렇다

(3)

(4)

많이 그렇다

(4)

많이 그렇다

(4)

많이 그렇다

(4)

많이 힘들다

(4)

많이 힘들다

(4)

많이 그렇다
(5)

매우 많이 그렇다

(5)

매우 많이 그렇다

(5)

매우 많이 그렇다

(5)

매우 많이 힘들다

(5)

매우 많이 힘들다

(5) 
Supplementary Table 2. Psychological responses impacted on personal quality of life in COVID-19 pandemic

\begin{tabular}{|c|c|c|c|c|c|c|c|c|c|c|c|c|c|c|c|c|}
\hline & \multicolumn{4}{|c|}{ Physical health } & \multicolumn{4}{|c|}{ Psychological health } & \multicolumn{4}{|c|}{ Social relationships } & \multicolumn{4}{|c|}{ Environment } \\
\hline & $\mathrm{B}$ & SE & Beta & $\mathrm{p}$ & $\mathrm{B}$ & SE & Beta & $\mathrm{p}$ & B & SE & Beta & $\mathrm{p}$ & B & SE & Beta & $\mathrm{p}$ \\
\hline Worry about getting infected & 0.038 & 0.072 & 0.021 & 0.600 & 0.031 & 0.080 & 0.015 & 0.697 & -0.082 & 0.100 & -0.032 & 0.411 & 0.054 & 0.083 & 0.025 & 0.514 \\
\hline Worry about financial difficulties & -0.041 & 0.064 & -0.024 & 0.522 & -0.179 & 0.072 & -0.093 & 0.013 & -0.324 & 0.090 & -0.137 & $<0.001$ & -0.275 & 0.075 & -0.139 & $<0.001$ \\
\hline Worry about interpersonal relationship & 0.055 & 0.075 & 0.031 & 0.461 & -0.020 & 0.083 & -0.010 & 0.814 & 0.122 & 0.104 & 0.049 & 0.240 & -0.083 & 0.086 & -0.040 & 0.335 \\
\hline Distress in complying personal hygiene & 0.185 & 0.078 & 0.093 & 0.018 & 0.174 & 0.087 & 0.077 & 0.056 & -0.049 & 0.109 & -0.018 & 0.652 & -0.024 & 0.090 & -0.010 & 0.794 \\
\hline Distress in keeping social distancing & 0.060 & 0.063 & 0.036 & 0.338 & 0.185 & 0.070 & 0.096 & 0.008 & 0.168 & 0.087 & 0.071 & 0.046 & 0.111 & 0.073 & 0.056 & 0.127 \\
\hline Seeking something to do alone & 0.237 & 0.071 & 0.125 & 0.001 & 0.450 & 0.079 & 0.208 & 0.000 & 0.228 & 0.098 & 0.087 & 0.020 & 0.383 & 0.082 & 0.173 & $<0.001$ \\
\hline Age & 0.003 & 0.007 & 0.018 & 0.678 & -0.014 & 0.008 & -0.073 & 0.083 & -0.019 & 0.010 & -0.082 & 0.057 & -0.012 & 0.008 & -0.065 & 0.125 \\
\hline Sex (ref: male) & -0.245 & 0.145 & -0.056 & 0.090 & -0.271 & 0.161 & -0.054 & 0.092 & 0.218 & 0.201 & 0.036 & 0.279 & -0.169 & 0.167 & -0.033 & 0.314 \\
\hline Educational level (ref: 12 years and under) & -0.313 & 0.172 & -0.064 & 0.070 & -0.148 & 0.192 & -0.026 & 0.442 & -0.736 & 0.240 & -0.108 & 0.002 & -0.352 & 0.200 & -0.061 & 0.079 \\
\hline Occupational status (ref: unemployed or retired) & 0.562 & 0.241 & 0.077 & 0.020 & 0.552 & 0.269 & 0.066 & 0.040 & 0.807 & 0.336 & 0.079 & 0.017 & 0.336 & 0.279 & 0.039 & 0.229 \\
\hline Marital status (ref: never married) & -0.157 & 0.155 & -0.043 & 0.311 & -0.002 & 0.173 & 0.000 & 0.993 & 0.198 & 0.216 & 0.038 & 0.361 & -0.150 & 0.180 & -0.035 & 0.405 \\
\hline Religion (ref: no) & 0.184 & 0.147 & 0.041 & 0.212 & 0.299 & 0.164 & 0.058 & 0.070 & 0.554 & 0.205 & 0.089 & 0.007 & 0.396 & 0.171 & 0.076 & 0.021 \\
\hline No. of family member (ref: living alone) & -0.055 & 0.231 & -0.008 & 0.812 & -0.366 & 0.258 & -0.046 & 0.156 & 0.159 & 0.322 & 0.017 & 0.621 & -0.182 & 0.268 & -0.023 & 0.497 \\
\hline Monthly household income (ref: below 2 million KRW) & 0.134 & 0.046 & 0.104 & $<0.001$ & 0.241 & 0.052 & 0.164 & $<0.001$ & 0.249 & 0.065 & 0.139 & $<0.001$ & 0.303 & 0.054 & 0.201 & $<0.001$ \\
\hline $\mathrm{aR}^{2}$ & \multicolumn{4}{|c|}{0.141} & \multicolumn{4}{|c|}{0.145} & \multicolumn{4}{|c|}{0.152} & \multicolumn{4}{|c|}{0.181} \\
\hline
\end{tabular}

B: unstandardized regression coefficient, SE: standard error, Beta: standardized regression coefficient, $\mathrm{aR}^{2}$ : adjusted R-squared 